\title{
Effects of Dietary Fortification of Vitamin A and Folic Acid on the Composition of Chicken Egg
}

\author{
M.J. Ogundare and S.A. Bolu \\ Department of Animal Production, University of Ilorin, Ilorin \\ Nigeria
}

\section{Introduction}

Micronutrient Malnutrition (MNM) is widespread in the industrialized nations, but more prominent in the developing regions of the world. It affects human of all age groups, but young children and women of reproductive age tend to be among the high-risk groups of micronutrient deficiencies. Micronutrient malnutrition has many adverse effects on human health, some of which, are clinically evident. At moderate levels of deficiency (which can be detected by biochemical or clinical measurements) MNM can have serious detrimental effects on human biological functions. Thus, in addition to the obvious and direct health effects, MNM has profound implications for economic development and productivity, particularly in terms of the potentially huge public health costs and the loss of human capital formation.

Fortification is the practice of deliberately increasing the content of an essential micronutrient, i.e. vitamins and minerals (including trace elements) in a food, so as to improve the nutritional quality of the food supply and provide a public health benefit with minimal risk to health (Lindsay et al., 2006). Fortification of food with micronutrients is a valid technology for reducing micronutrient malnutrition as part of a food-based approach. Food fortification is particularly imperative when and where existing food supplies and limited access fail to provide adequate levels of the respective nutrients in the diet. In such cases, food fortification reinforces and supports ongoing nutrition improvement programmes and should be regarded as part of a broader, integrated approach to prevent $\mathrm{MNM}$, thereby complementing other approaches to improve micronutrient status. The public health significance of food fortification is a function of: helping the at-risk population to reach the biological efficacious threshold of micronutrient intake through the consumption of fortified food; and keeping the intake below levels that may cause adverse effects due to excesses (toxicity) on individuals who consume the fortified food in large amounts.

Food fortification is a deliberate addition of one or more micronutrients to particular foods, for the purpose of increasing the intake of these micronutrients and consequently, correct or prevent a demonstrated deficiency. It has the dual advantage of being able to deliver nutrients to large segments of the population without radical changes in food consumption patterns (Lofti, 1996). In developed countries, food fortification has proven an effective and 
low-cost way to increase the micronutrient supply and reduce the consequences of micronutrient deficiencies (Omar and Jose, 2002).

Food fortification, unlike other forms of MNM interventions does not necessitate a change in dietary patterns of the population, can deliver a significant proportion of the recommended dietary allowances for a number of micronutrients on a continuous basis, and does not demand for individual compliance. Nutrients to be fortified are often be incorporated into the existing food production and distribution system, and therefore, can be sustained over a long period of time. Food fortification is a more cost-effective and sustainable solution. It plays a major role in improving the diet and meeting the micronutrient needs of the population. It is also an integrated food-based strategy; other strategies include dietary diversification, homestead production, development of national food and improved food processing and storage.

The technical considerations in food fortification include selection of appropriate food vehicles that are consumed by a sizeable proportion of the population and lend themselves to centralized processing on an economical scale. The product should be one that is distributed through a wide network so that it reaches all parts of the country.

Food fortification has a long history of use in industrialized countries for the successful control of deficiencies of vitamin A and D, several B vitamins (thiamin, riboflavin and niacin), iodine and iron. Salt iodization was introduced in the early 1920s in both Switzerland (Burgi et al., 1990) and the United States of America (Marine and Kimball, 1920) and has since expanded progressively all over the world to the extent that iodized salt is now used in most countries.

From the early 1940s, the fortification of cereal products with thiamine, riboflavin and niacin became common practice. Margarine was fortified with vitamin A in Denmark and milk with vitamin D in the United States. Foods for young children were fortified with iron, a practice which has substantially reduced the risk of iron-deficiency anaemia in this age group.

In more recent years, folic acid fortification of wheat has become widespread in the Americas, a strategy adopted by Canada and the United States and about 20 Latin American countries (Lindsay et al., 2006). Being a food-based approach, food fortification offer a number of advantages over other interventions aimed at preventing and controlling micronutrient malnutrition (World Bank, 1994).

The burden of malnutrition in Africa and other developing economy is a major global concern. Malnutrition in its various manifestations has resulted loss of productivity. This is a direct is a direct consequence of the effects of lack of essential nutrients, vitamins and minerals in particular (WHO, 2002). Interest in micronutrient malnutrition has increased greatly over the last few years because it contributes substantially to the global burden of disease. More than 2 billion people in the world today suffer from micronutrient deficiencies caused largely by a dietary deficiency of vitamins.

In 2000, the World Health Report identified iron, vitamin A and zinc deficiencies as micronutrients that contributed to serious health risk factors (Lindsay et al., 2006).Vitamin A deficiency is a major global problem affecting populations in developing areas of more than seventy-five countries where clinical and subclinical conditions have been observed (Summer and Davidson, 2002; WHO,2003). It has also been reported that $41 \%$ of population 
under 5 years of age in developing countries suffers from inadequate vitamin A intake. This has resulted to about half a million of children going blind each year and thirteen and half million develop night-blindness yearly (WHO, 2000).

Populations in malaria-endemic areas are known to be at high risk of folate deficiency. In certain parts of Africa, malaria illness during pregnancy has been reported as the most common cause of megaloblastic erythropoiesis (Fleming, 1989). This is due to extensive haemolysis occasioned by malaria as well as, suppression of erythropoiesis. As a result of increased red cell turnover (i.e. erythroid hyperplasia), folate requirement is further increased, especially during pregnancy when folate requirements are already high for maternal and fetal tissue growth (O'Conner, 1994).

Supplements, usually in the form of pills, capsules or syrups had been used to provide relatively large doses of micronutrients. Nationwide supplementation programmes combined to supplement children once or twice a year with high-doses of Vitamin A are combined in at least 43 countries with National Immunization Days (Klemm et al., 1997).

Though supplementation is often the fastest way to control identified deficiencies, it however requires the procurement and purchase of micronutrients in relatively expensive pre-packaged forms, an effective distribution system and a high degree of consumer compliance (especially for water-soluble vitamins prescribed for use on a long term basis). Irregular supplies and poor compliance has been reported by many supplementation programme managers as being the major constraints to success (Lindsay et al., 2006; Maria and Bruno, 2002).

Among the different foods delivering essential nutrients to the human body, egg is important, because it supplies rich and balanced source of essential amino acids, fatty acids as well as some minerals and vitamins (Surai and Sparks, 2001). Research has shown that the levels of many nutrients found in hen's eggs can be altered by altering their level in the hen's diet (Gibson, 2000).

In this study, we manipulated vitamin A and folate fortification in laying hens diet to increase their eggs content. The success of this study may position the egg as an important source of these dietary vitamins and lead to an improvement in consumer acceptance of this commodity as a healthful product. This is of paramount relevance to the vulnerable human groups for these nutrients e.g. children and pregnant women.

\section{Materials and methods}

Two hundred (200) Black Harco pullets (23 weeks old) were fed a standard layers mash. The pullets were monitored for egg production and health status for 2 weeks. One hundred and forty (140) highest-producing and healthy laying hens were selected from this population for the study. The selected hens were divided into seven groups of five replicates per group. Each replicate containing 4 birds ( 20 birds per treatment) were randomly allocated to a two tier cage with cell dimensions of $38 \mathrm{~cm} \times 40 \mathrm{~cm}$. Birds were given water and feed (Table 1) ad libitum for a study period of eight weeks. Vitamin A capsules containing water miscible retinyl palmitate beadlet called "25-CWS" (CWS-cold water soluble) was administered orally to individual birds with the aid of a sterilized syringe while the synthetic feed grade monoglutamate form of folate-folic acid (Dr Meyers) used was incorporated into the diet. 
Feed intake and body weight gain were recorded weekly. Hen-day production, feed utilization efficiency were calculated. Weights of egg, albumen, yolk and shell samples were measured. Albumen height was measured with a spherometer, shell thickness with a micrometer screw gauge and egg length and breadth with a vernier caliper. Egg albumen quality (Haugh units) and yolk index were calculated (Bolu and Balogun, 1998)

Vitamin A analysis of four eggs per treatment was carried out using standard HPLC analytical procedures as outlined for vitamin A determination (Nielsen, 2002). The concentration of 5-methyltetrahydrofolate in egg yolk extracts was determined by reversephase HPLC with fluorescence detection, as described by Vahteristo et al., (1997).

At the end of the study, blood samples were taken from the wing vein of six (6) birds from each treatment into bijou bottles containing EDTA (anticoagulant). Packed cell volume (PCV), haemoglobin concentration $(\mathrm{Hb})$, total RBC and total WBC were evaluated according to Dacie and Lewis (1977). Plasma obtained from centrifugation of was used to determine alkaline phosphatase (AP.EC.3.1.3.1) activity by the kinetic method of (Frajola et al., 1965). Proximate analysis of the basal diet was carried out according to the method described by (AOAC 1990). Response criteria were subjected to analysis of variance (ANOVA) using the SPSS statistical package (SPSS, Inc., 2000). Differences between treatment means were separated using Duncan Multiple Range Test (Duncan, 1995).

\begin{tabular}{|l|c|}
\hline \multicolumn{1}{|c|}{ Ingredients } & Quantity (kg) \\
\hline Maize & 45 \\
Corn bran & 10 \\
Wheat offal & 5.9 \\
Groundnut cake & 19 \\
Brewers Dried Grain & 5.0 \\
Soybean Meal & 2.0 \\
Palm kernel cake & 3.0 \\
Fishmeal & 1.0 \\
Bone meal & 0.27 \\
Oyster Shell & 8.0 \\
Salt & 0.3 \\
Lysine & 0.1 \\
Methionine & 0.15 \\
Toximil & 0.03 \\
\hline & 100.00 \\
\hline Calculated nutrient composition & \\
Crude Protein (\%) & 17.94 \\
Metabolizable energy (Kcal/kg) & 2672.67 \\
\hline
\end{tabular}

Table 1a. Composition of Basal Diet (/100kg feed) 


\begin{tabular}{|c|c|c|c|c|c|c|c|}
\hline \multirow{2}{*}{ Ingredients } & \multicolumn{7}{|c|}{ Diets } \\
\hline & 1 & 2 & 3 & 4 & 5 & 6 & 7 \\
\hline Basal diet & + & + & + & + & + & + & + \\
\hline 3,750 i.u vit $\mathrm{A} / \mathrm{kg}$ diet & + & & & & & & \\
\hline Commercial premix* (+ve control) & & & + & & & & \\
\hline $0.5 \mathrm{mg}$ folate $/ \mathrm{kg}$ diet & & & + & & & & \\
\hline $1.0 \mathrm{mg}$ folate/kg diet & & & & + & & & \\
\hline 7,500 i.u vit $\mathrm{A} / \mathrm{kg}$ diet & & & & & + & & \\
\hline 7,500 i.u.vit $\mathrm{A}+1.0 \mathrm{mg}$ folate/ $\mathrm{kg}$ diet & & & & & & + & \\
\hline -ve control & & & & & & & + \\
\hline
\end{tabular}

*provided (per 2.5kg of diet), vitamin A (i.u) 10,000,000, vitamin $\mathrm{D}_{3}$ (i.u) 2, 000, 000, vit. E (i.u) 12, 000, vit. K (mg) 2,000, Thiamin (mg) 1,500, Riboflavin (mg) 4,000, Pyridoxine (mg) 1,500, Niacin (mg)15,000, Cyanocobalamin (mcg) 10,Panthothenic acid (mg) 5,000, Folic acid(mg) 500, Biotin (mcg) 20,Choline chloride (mg) 100,000,Manganese (mg) 75,000, Zinc (mg) 50,000, Iron (mg) 20,000,Copper(mg) 5,000, Iodine (mg) 1,000,Selenium (mg) 200, Cobalt(mg) 500, Antioxidant (mg) 125,00

Table 1b. Composition of Experimental Diet

\section{Results and discussion}

The performance and egg quality parameters of laying pullets fed the different treatments did not vary $(\mathrm{P}>0.05)$ except for egg weight (Table 2$)$. This observation corroborates the reports Hebert et al., (2004) and Lin et.al, 2002 that supplemental Folic acid and vitamin A respectively, did not affect body weight change of experimental hens. Folic acid levels have been reported not to affect feed consumption (Hebert et al. 2005). In the same vein, Lin et al., 2002 reported that neither the vitamin A supplemental levels nor the treatment regimens had a significant effect on feed intake or laying performance of experimental hens $(P>0.05)$.

Significant differences $(\mathrm{P}<0.05)$ observed in the values of egg weight was due to dietary treatments. Birds fed $100 \%$ dietary inclusion of folic acid had the highest egg weight $(61.74 \mathrm{~g})$ while the lowest value of egg weight (56.83g) was recorded for birds fed $200 \%$ dietary inclusion of vitamin A. Herbert e al. (2005) observed in a study of diet $\times$ strain interaction that higher egg mass was a result of increased folic acid supplementation. March et al. (1972) reported a decrease in egg weight and a marked decline in the hen-day egg production at higher levels of vitamin A supplementation.

The results of the haematological indices and serum enzyme are shown on Table 3. Significant differences were observed among the dietary treatments, The values of the PCV of all the treatments were within the normal range $(18.5-45.2 \%)$ reported by Mitruka and Rawnsely (1977) though treatments 4 and 6 were significantly lower than the others. The results obtained for haemoglobin concentration $(\mathrm{Hb})$ followed the same pattern with that of PCV. The function of the blood in transporting hormones, metabolites, as thermo-regulators and general homeostasis has been clearly established (Duke, 1975). The haematological examination of the present study showed no adverse effect on the health status of the 
experimental birds as a result of the dietary fortification of vitamin A and Folic acid. Phosphatase enzymes are already detectable in the chick embryo as early as the first 5 days of incubation and it is an indirect assessment of bone mineralization (Needham, 1963). Values obtained from this study showed that dietary fortification of vitamins A and Folic acid does not impair calcium and phosphorus utilization for bone mineralization.

\begin{tabular}{|c|c|c|c|c|c|c|c|}
\hline \multirow{2}{*}{ Egg laying index } & \multicolumn{7}{|c|}{ Diets $^{A}$} \\
\hline & 1 & 2 & 3 & 4 & 5 & 6 & 7 \\
\hline Average initial weight (kg/bird) & 1.46 & 1.51 & 1.55 & 1.43 & 4.50 & 1.50 & 1.55 \\
\hline Final body weight (kg/bird) & 1.55 & 1.53 & 1.61 & 1.50 & 1.55 & 1.55 & 1.54 \\
\hline Weight change (g/bird/week) & 1.63 & 1.35 & 1.13 & 1.28 & 1.17 & 0.96 & 0.64 \\
\hline Feed intake $(\mathrm{g} / \mathrm{d})$ & 122.29 & 113.64 & 119.85 & 117.42 & 110.04 & 118.29 & 114.05 \\
\hline Feed efficiency (kg/dozen eggs) & 2.37 & 2.43 & 2.50 & 2.40 & 2.36 & 2.57 & 2.51 \\
\hline Hen-day egg production (\%) & 14.48 & 14.92 & 15.32 & 14.72 & 14.54 & 15.77 & 15.41 \\
\hline Egg weight (g) & 64.82 & 58.92 & 61.07 & 62.67 & 61.07 & 59.10 & 57.32 \\
\hline Albumen height (mm) & $57.87 \mathrm{ab}$ & $57.54^{\mathrm{ab}}$ & $61.74^{c}$ & $58.25^{\mathrm{ab}}$ & $56.83^{a}$ & $58.24^{\mathrm{ab}}$ & $59.62^{b c}$ \\
\hline Egg shell thickness (mm) & 6.13 & 6.28 & 6.35 & 6.31 & 6.42 & 5.87 & 5.62 \\
\hline Yolk index ${ }^{B}$ & 3.95 & 3.98 & 4.04 & 4.03 & 4.01 & 3.96 & 3.89 \\
\hline Haugh Unit* $(\%)$ & 75.92 & 77.19 & 76.94 & 77.94 & 79.27 & 72.65 & 71.64 \\
\hline Liveability (\%) & 100.0 & 100.0 & 100.0 & 100.0 & 100.0 & 100.0 & 100.0 \\
\hline
\end{tabular}

abc: Means in the same column with different superscripts are significantly different $(\mathrm{P}<0.05)$. A1=basal diet+3,750 IU retinyl palmitate; 2 : basal diet with premix alone (+ve control); 3: basal diet+ $0.5 \mathrm{mg}$ folic acid/ $\mathrm{kg}$; 4 : basal diet+1.0mg folic acid; 5 : basal diet+7,500 IU retinyl palmitate; 6 : basal diet+ $7500 \mathrm{IU}$ retinyl palmitate $+1.0 \mathrm{mg}$ folic acid/ kg; 7: basal diet without premix and fortification (- ve control).

Table 2. Effects of Dietary Fortification of Vitamin A and Folic Acid on Performance and Egg Quality Parameters of Laying Hens.

The results of egg yolk retinol and folate concentrations are shown on Tables 4 and 5 respectively. Regression analysis clearly showed a significant positive correlation between dietary retinyl palmitate and egg retinol $(r=0.813)$. The regression equation was $y=$ $0.1172 x+528.175$, where $y$ is egg retinol (i.u/100g), and $x$ is dietary retinyl palmitate (i.u/ $\mathrm{kg}$ ), indicating that egg retinol increased linearly as dietary vitamin A rose. These data are in agreement with previous reports indicating the influence of dietary vitamin A on its concentration in the egg yolk (Squires and Naber, 1993; Qui and Sim, 1998). The addition of increasing levels of dietary folic acid showed a trend to reduce the yolk retinol content, decreasing in 47.69 , and $34.03 \%$, respectively for 0.5 , and $1.0 \mathrm{mg}$ of supplemental folic acid/kg of diet, in comparison with the control group (Table 4). These results, however, proved to be not significant. 


\begin{tabular}{|lccccccc|}
\hline \multirow{2}{*}{ Haematological Indices } & \multicolumn{7}{c|}{ Diets/Treatments } \\
\cline { 2 - 8 } & $\mathbf{1}$ & $\mathbf{2}$ & $\mathbf{3}$ & $\mathbf{4}$ & $\mathbf{5}$ & $\mathbf{6}$ & $\mathbf{7}$ \\
\hline Packed cell volume (\%) & $24^{\mathrm{ab}}$ & $22^{\mathrm{ab}}$ & $27^{\mathrm{bc}}$ & $19^{\mathrm{a}}$ & $22^{\mathrm{ab}}$ & $19^{\mathrm{a}}$ & $28^{\mathrm{c}}$ \\
Heamoglobin (g/1) & $4.7^{\mathrm{d}}$ & $3.79^{\mathrm{b}}$ & $5.20^{\mathrm{e}}$ & $4.00^{\mathrm{c}}$ & $4.00^{\mathrm{c}}$ & $3.5^{\mathrm{a}}$ & $5.25^{\mathrm{e}}$ \\
Red Blood cell (1012/1) & $1.15^{\mathrm{b}}$ & $1.16^{\mathrm{b}}$ & $1.90^{\mathrm{c}}$ & $1.00^{\mathrm{a}}$ & $1.20^{\mathrm{b}}$ & $1.13^{\mathrm{ab}}$ & $1.93^{\mathrm{c}}$ \\
White Blood cell (109/1) & $8.9^{\mathrm{ab}}$ & $9.1^{\mathrm{b}}$ & $10.3^{\mathrm{d}}$ & $12.9^{\mathrm{e}}$ & $8.7^{\mathrm{a}}$ & $10.1^{\mathrm{d}}$ & $9.7^{\mathrm{c}}$ \\
Neutrophils (\%) & $19 \mathrm{a}$ & $26^{\mathrm{b}}$ & $26^{\mathrm{b}}$ & $32^{\mathrm{d}}$ & $29 \mathrm{c}$ & $27_{\mathrm{bc}}$ & $20^{\mathrm{a}}$ \\
Lymphocytes (\%) & $79^{\mathrm{d}}$ & $73^{\mathrm{c}}$ & $74^{\mathrm{c}}$ & $66^{\mathrm{a}}$ & $70^{\mathrm{b}}$ & $70^{\mathrm{b}}$ & $80^{\mathrm{d}}$ \\
Monocytes (\%) & 2 & 0 & 0 & 1 & 1 & 3 & 0 \\
Eosinophils (\%) & 0 & 1 & 0 & 1 & 0 & 0 & 0 \\
SERUM ENZYME & & & & & & & \\
Plasma alkaline phosphatase & $8^{\mathrm{a}}$ & $16^{\mathrm{c}}$ & $10^{\mathrm{b}}$ & $20^{\mathrm{d}}$ & $8^{\mathrm{a}}$ & $22^{\mathrm{e}}$ & $10^{\mathrm{b}}$ \\
\hline
\end{tabular}

abcd: Means in the same column with different superscripts are significantly different $(\mathrm{P}<0.05)$.

Table 3. Effects of Dietary Fortification of Vitamin A and Folic Acid on the Haematology and Serum Enzyme of Laying Hens.

\begin{tabular}{|c|c|c|c|c|}
\hline \multicolumn{5}{|l|}{ Treatments $^{1-7}$} \\
\hline $\begin{array}{c}\text { Vitamin A } \\
\text { supplementation } \\
\text { (IU/kg of diet) }\end{array}$ & $\begin{array}{c}\text { Folic Acid } \\
\text { supplementation } \\
\text { (mg/kg of diet) }\end{array}$ & $\begin{array}{c}\text { Yolk retino } \\
\text { (IU/100g of yolk) }\end{array}$ & $\begin{array}{l}\text { Yolk retinol } \\
\text { ( } \% \text { change) }\end{array}$ & $\begin{array}{c}\text { Correlation } \\
\text { coefficient } \\
\text { (r) }\end{array}$ \\
\hline 1 & 3,750 & 0 & $604.02^{a}$ & $-8.2^{\mathrm{B}}$ \\
\hline 2 & 0 & 0 & $658.01^{a}$ & ------ \\
\hline 3 & 0 & 0.5 & $592.98 \mathrm{a}$ & $-9.8^{\mathrm{B}}$ \\
\hline 4 & 0 & 1.0 & $915.97 b$ & $+39.2^{\mathrm{B}}$ \\
\hline 5 & 7,500 & 0 & $2597.9 c$ & $+294.8^{\mathrm{B}}$ \\
\hline 6 & 7,500 & 1.0 & 580 a & $-11.9^{\mathrm{B}}$ \\
\hline 7 & 0 & 0 & $675^{a}$ & $+2.6^{\mathrm{B}}$ \\
\hline \multicolumn{5}{|c|}{ Vitamin A supplementation (IU/kg of diet) } \\
\hline 0 & & 710 & ------ & \\
\hline 3.750 & & 604.02 & $-14.93 \mathrm{C}$ & $0.813 \mathrm{E}$ \\
\hline 7.500 & & 1588.99 & $+123.80^{\mathrm{C}}$ & \\
\hline \multicolumn{5}{|c|}{ Folic Acid supplementation (mg/kg of diet) } \\
\hline 0 & & 1133.75 & ----- & \\
\hline 0.5 & & 592.98 & $-47.69 \mathrm{D}$ & ------ \\
\hline 1.0 & & 747.99 & $-34.03 \mathrm{D}$ & ------ \\
\hline
\end{tabular}

abc: Means in the same column with different superscripts are significantly different $(\mathrm{P}<0.05)$.

1-71=basal diet+3,750 IU retinyl palmitate; 2: basal diet with premix alone (+ve control); 3: basal diet+ $0.5 \mathrm{mg}$ folic acid $/ \mathrm{kg}$; 4 : basal diet+1.0mg folic acid; 5 : basal diet+7,500 IU retinyl palmitate; 6 : basal diet+ 7500 IU retinyl palmitate+1.0mg folic acid/kg; 7: basal diet without premix and fortification (- ve control). BPercentage change in comparison to the +ve control group.

cPercentage of yolk retinol in comparison with no Vitamin A supplementation.

D Percentage of yolk retinol in comparison with no Folic Acid supplementation.

ECorrelation coefficient between yolk retinol and dietary Vitamin A supplementation, whole data, regardless of levels of supplemental Folic Acid.

Table 4. Egg yolk Retinol (iu/100g of yolk), Percentage of change, and Correlation Coefficients. 
Significant and progressive incorporation of folate into the egg yolk was achieved by feeding laying hens a basal diet supplemented with increasing levels of folic acid, regardless of supplemental vitamin A. The regression analysis was significant $(r=0.971)$, and the regression equation was $y=154 x+106.74$, where $y$ is egg folate $(\mu \mathrm{g} / 100 \mathrm{~g})$, and $x$ is dietary Folic acid $(\mathrm{mg} / \mathrm{kg})$, indicating that egg folate increased linearly as dietary Folic acid increased. House et al., (2002) and the work of others (Sherwood et al., 1993), reported that egg folate concentrations responded to increasing levels of dietary folic acid supplementation of crystalline folic acid per kilogram of diet.

\begin{tabular}{|c|c|c|c|c|c|}
\hline \multicolumn{6}{|c|}{ Treatments ${ }^{1-7}$} \\
\hline & $\begin{array}{c}\text { Vitamin A } \\
\text { supplementation } \\
\text { (IU/kg of diet) }\end{array}$ & $\begin{array}{c}\text { Folic Acid } \\
\text { supplementation } \\
\text { (mg/kg of diet) }\end{array}$ & $\begin{array}{c}\text { Egg Folate } \\
(\mu / 100 g \text { of yolk) }\end{array}$ & $\begin{array}{l}\text { Yolk Folate } \\
\text { ( } \% \text { change) }\end{array}$ & $\begin{array}{c}\text { Correlation } \\
\text { coefficient } \\
\text { (r) }\end{array}$ \\
\hline 1 & 3,750 & 0 & $93.09 a$ & $-10.8^{\mathrm{B}}$ & \\
\hline 2 & 0 & 0 & $104.34^{a}$ & ------ & \\
\hline 3 & 0 & 0.5 & $205.64^{c}$ & $+97.08^{B}$ & \\
\hline 4 & 0 & 1.0 & $323.48^{d}$ & $+210.02^{\mathrm{B}}$ & \\
\hline 5 & 7,500 & 0 & $92.63^{a}$ & $-11.22^{\mathrm{B}}$ & \\
\hline 6 & 7,500 & 1.0 & $176.11^{b}$ & $+68.78^{B}$ & \\
\hline 7 & 0 & 0 & $93.12^{\mathrm{a}}$ & $-10.75^{\text {В }}$ & \\
\hline \multicolumn{6}{|c|}{$\begin{array}{l}\text { Vitamin A supplementation } \\
\text { (IU/kg of diet) }\end{array}$} \\
\hline & 0 & & 181.65 & ------ & \\
\hline & 3.750 & & 93.09 & $-48.75 \mathrm{C}$ & ------ \\
\hline & 7.500 & & 134.37 & $-26.02^{C}$ & ------ \\
\hline \multicolumn{6}{|c|}{$\begin{array}{l}\text { Folic Acid supplementation } \\
\text { (mg/kg of diet) }\end{array}$} \\
\hline & 0 & & 95.79 & ------ & \\
\hline & 0.5 & & 205.64 & $+114.67 \mathrm{D}$ & ------ \\
\hline & 1.0 & & 249.79 & $+160.61^{\mathrm{D}}$ & $0.971^{\mathrm{E}}$ \\
\hline
\end{tabular}

abcd: Means in the same column with different superscripts are significantly different $(\mathrm{P}<0.05)$.

1-71=basal diet+3,750 IU retinyl palmitate; 2 : basal diet with premix alone (+ve control); 3: basal diet+

$0.5 \mathrm{mg}$ folic acid/ $\mathrm{kg}$; 4 : basal diet+1.0mg folic acid; 5 : basal diet+7,500 IU retinyl palmitate; 6 : basal diet+ $7500 \mathrm{IU}$ retinyl palmitate+ $1.0 \mathrm{mg}$ folic acid $/ \mathrm{kg}$; 7 : basal diet without premix and fortification (- ve control).

BPercentage change in comparison to the +ve control group.

cPercentage of yolk folate in comparison with no Vitamin A supplementation.

D Percentage of yolk folate in comparison with no Folic Acid supplementation.

ECorrelation coefficient between yolk folate and dietary Folic acid supplementation, whole data, regardless of levels of supplemental Vitamin A.

Table 5. Egg Yolk Folate (mg/100g Yolk), Percentage of Change, and Correlation Coefficients.

Supplementation with increasing amounts of dietary vitamin A produced significant reductions in average egg yolk folate concentrations of 48.75 and $26.02 \%$, respectively, for eggs from hens fed 3,750 and 7,000 i.u of supplemental vitamin A/kg (Table 5).

Generally, the findings of this study further reinforce the need to profitably produce enriched eggs in a sustainable way through fortification. Individual fortifications of vitamin A and folic 
acid at $200 \%$ inclusion level of NRC recommendations which was significantly better in overall performance and egg yolk vitamin deposit would be recommended until further studies are carried out to elucidate the interactions between vitamin A and Folic acid.

\section{References}

A.O.A.C. (1990). Official Methods of Analysis. 15th ed. Association of Official Analytical Chemists. Arlington, VA.

Cavalli-Sforza, T. and Bosch, D. (2000). Food fortification as part of an integrated food and nutrition strategy. In: Manila Forum 2000: Strategies to fortify essential foods in Asia and the Pacific. Asian Development Bank, International Life Sciences Institute, Washington, DC, Micronutrient Initiative, Ottawa, Canada. pp. 351-52

Dacie, J.W. and Lewis, S.M. (1977). Practical haematology. 5th. Ed. Longman Group Ltd. $\operatorname{Pg} 21-68$.

Duke H.H. (1975). Duke;s Physiology of Domestic Animal Textbook. $8^{\text {th }}$ edition. Ithae and London constock publishing Associate.

Duncan, D.B. (1955). Multiple Range and F-Test Biometric: 11:1-42.

El-Husseiny, O.M., Soliman, A.Z., Abd-Elsamee, M.O. and Omara, I.I. (2005). Effect of dietary energy methionine, choline and folic acid levels on layers performance. Egy. Poult. Sci. J., 25: 931-956.

Fitzgerald, S. (1997). Fortification rapid assessment guidelines and tool (FRAT) Path Canada.

Fleming, A.F. (1989). The aetiology of pregnancy in tropical Africa. Trans R Soc Trop. Med Hyg 83: 441-448.

Frajola, W.J., William, R.D. and Austin, R.A. (1965). The kinetic spectrophotometric assay for serum Alkaline Phosphatase. Am. J. Clin. Path. 43:261-264.

Gibson, R. (2000). Literature and Patent Search to determine the feasibility of developing eggs with specific nutrients. RIRDC Completed Projects in 1999-2000.

Hebert, K., House, J.D. and Guenter, W. (2004). Efficiency of folate deposition in eggs through-out the production cycle of Hy-line W98 and W36 laying hens. Poult. Sci., 83: (suppl.1).

Herbert, K., House, J.D. and Guenter, W. (2005). Effect of dietary folic acid supplementation on egg folate content and the performance and folate status of two strains of laying hens. Poult.Sci. 84: 1533-1538.

House, J.D., Braun, K., Balance, D.M., O'Connor, C.P. and Guenter, W. (2002). The enrichment of eggs with folic acid through supplementation of the laying hen diet. Poult Sci.81: 1332-1337.

Klemm, R.D.W., Ungson, B.D., Lopez, C.T., Villate, E.E., Ramos, A.C., Serdooncillo, M., Paulino, L.S., Longaza, S.G., Guarin, R.M., Tirazona, A.M. and Borata, F.R. (1997). Coverage and factors associated with vitamin A, iron and iodine supplementation during the National Micronutrient Day 1996 in Samar and Albay. Mimeo. USAID HKI, 1997.

Lindsay, A., Omar, D. and Richard, H. (2006). Guidelines on food fortification with micronutrients. WHO Library Catalouging- in- Publication.

Lin, H., Wang, L.F., Song, J.L., Xie, Y.M. and Yang, Q.Y. (2002). Effect of Dietary Supplemental Levels of Vitamin A on the Egg Production and Immune Responses of Heat-Stressed Laying Hens. Poultry Science 81:458-465 
Lofti M. (1996). Micronutrient fortification of foods: current practices, research and opportunities. Ottawa, Micronutrient Initiative, International Agricultural Centre.

March, B. E., Coates, V and Goudie, C. (1972). Delayed hatching time of chicks from dams fed excess vitamin A and from eggs injected with vitamin A. Poult. Sci. 51:891-896.

Maria, A. and Bruno de Benoist. (2002). Vitamin A Deficiency Control. /UNICEF Strategy. Micronutrient and Trace Elements Unit Department of Nutrition for Health and Development World Health Organization Geneva

Micronutrient Initiative. (1997) Food fortification to end micronutrient malnutrition: Stateofthe-Art Symposium Report, 2 August 1997, Montreal, Canada. Ottawa, Micronutrient Initiative, International Agricultural Centre, 1998.

Miltruka, B.M and Rawnsley, H. (1977). In clinical, biochemical and heamatological values in normal experimental animals. 106-112. Masson Publishing. U.S.A Inc. new York.

Needham, J. (1963). Chemical Embryology. Hafner Publishing Comp, New York, London.

Neilsen, S.S. (2002). Introduction to the chemical analysis of food. Pg 253.CBS publishers. New Delhi.

O'Connor, D.L. (1994). Folate status during pregnancy and lactation. In: Nutrient regulation during pregnancy, lactation and infant growth. Allen L, King J, Lonnerdal B.(eds) Plenum Press, New York, pp. 157-172.

Omar, D. and Jose, O.M. (2002). Food Fortification to Reduce Vitamin A Deficiency: International Vitamin A Consultative Group Recommendations J. Nutr. 132:2927S2933S, September 2002.

Qui, G. H and Sim, J. S. (1998). Natural tocopherol enrichment and its effect in n-3 fatty acid modified chicken eggs. J. Agric. Food Chem. 46:1920-1926

Sherwood, I.A., Alphin, R.L., Saylor, W.W. and White, H.B. (1993). Folate metabolism and deposition in eggs by laying hens.Archives Biochem. Biophys., 307; 66-72.

Sommer, A. and Davidson, F.R. (2002). Assessment and Control of Vitamin A Deficiency: The Annecy Accords. J.Nutr. 132(9): 2845S-2850.

SPSS, Inc. (2000). SigmaPlot 2000 Graphical Software Package for Windows Version 10.0. Statistics Canada, 2001. CANSIM II Database. http://www.statcan.ca/english/Estat/licence. htm.

Squires, M.W. and Naber, E.C. (1993). Vitamin profiles of eggs as indicators of nutritional status in the laying hen: Riboflavin study. Poultry Sci. 72:483-494.

Surai, P.F. and Sparks, H.C. (2001). Designer eggs: from improvement of egg consumption to functional food. Anim. Feed Sci. Tech.12:7-16.

Vahteristo, L.T., Ollilainen, V and Varo, P.J. (1997). Liquid chromatographic determination of folate monoglutamates in fish meat, egg, and dairy products consumed in Finland. J.AOAC Int.80:373-8.

WHO. (2000). Vitamin A deficiency. WHO website updated 17 Feb 2000 http://www.who.int/vaccinesdiseases/diseases/vitamin_a.htm]

World Health Report. (2002). Reducing risks, promoting healthy life: overview. Geneve. World Health Organization.2002(WHO/WHR/02.1).

WHO (2003). Combating vitamin A deficiency. WHO website, updated September 2003. World Health Organisation, Rome, Italy. [http://www.who.int/nut/vad.htm] 


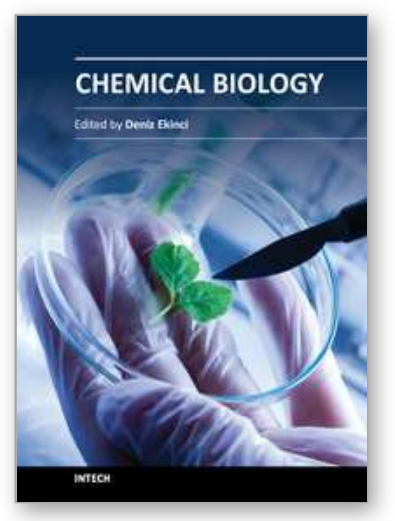

\author{
Chemical Biology \\ Edited by Prof. Deniz Ekinci
}

ISBN 978-953-51-0049-2

Hard cover, 444 pages

Publisher InTech

Published online 17, February, 2012

Published in print edition February, 2012

Chemical biology utilizes chemical principles to modulate systems to either investigate the underlying biology or create new function. Over recent years, chemical biology has received particular attention of many scientists in the life sciences from botany to medicine. This book contains an overview focusing on the research area of protein purification, enzymology, vitamins, antioxidants, biotransformation, gene delivery, signaling, regulation and organization. Particular emphasis is devoted to both theoretical and experimental aspects. The textbook is written by international scientists with expertise in synthetic chemistry, protein biochemistry, enzymology, molecular biology, drug discovery and genetics many of which are active chemical, biochemical and biomedical research. The textbook is expected to enhance the knowledge of scientists in the complexities of chemical and biological approaches and stimulate both professionals and students to dedicate part of their future research in understanding relevant mechanisms and applications of chemical biology.

\title{
How to reference
}

In order to correctly reference this scholarly work, feel free to copy and paste the following:

M.J. Ogundare and S.A. Bolu (2012). Effects of Dietary Fortification of Vitamin A and Folic Acid on the Composition of Chicken Egg, Chemical Biology, Prof. Deniz Ekinci (Ed.), ISBN: 978-953-51-0049-2, InTech, Available from: http://www.intechopen.com/books/chemical-biology/effects-of-dietary-fortification-of-vitamin-aand-folic-acid-on-the-composition-of-chicken-egg

\section{INTECH}

open science | open minds

\author{
InTech Europe \\ University Campus STeP Ri \\ Slavka Krautzeka 83/A \\ 51000 Rijeka, Croatia \\ Phone: +385 (51) 770447 \\ Fax: +385 (51) 686166 \\ www.intechopen.com
}

\author{
InTech China \\ Unit 405, Office Block, Hotel Equatorial Shanghai \\ No.65, Yan An Road (West), Shanghai, 200040, China \\ 中国上海市延安西路65号上海国际贵都大饭店办公楼 405 单元 \\ Phone: +86-21-62489820 \\ Fax: $+86-21-62489821$
}


(C) 2012 The Author(s). Licensee IntechOpen. This is an open access article distributed under the terms of the Creative Commons Attribution 3.0 License, which permits unrestricted use, distribution, and reproduction in any medium, provided the original work is properly cited. 